\title{
THE POTENTIAL OF PLANTS AND PLANT PRODUCTS IN STORED INSECT PEST MANAGEMENT
}

\author{
R.H.S. Rajapakse ${ }^{1}$
}

\begin{abstract}
In most of the tropical countries including Sri Lanka beetles attack store seeds and is a major cause of serious post harvest losses. In order to protect the stored product from insects not only pesticides but a formulation of plants and their products as powders, volatile oils, non volatile oils and extracts could be effectively used. An overview of available literature on use of plant products against the storage beetles in tropical regions is presented in order to highlight the importance, safe use, and effective control. Seed beetles cause an important part of the total insect damage to seed crops. The potential efficacy of a plant product can depend on the plant species, the plant part, and the time and way of harvesting. The mere fact that the natural products are used, implies that considerable variation is to be expected. Many of the tested plants do show effects against the seed beetles. The most effective plants or methods of application are not known, but results are promising and plant material can be an effective weapon in the battle against the beetles. Plants can be an effective replacement for chemical insecticides to protect stored seeds
\end{abstract}

Key Words: Post harvest losses, Storage beetle, Seed beetle, Insect pest management

\section{INTRODUCTION}

The legumes including Cowpea (Vigna unguiculata L.) Walp.) are an important crops in Sri Lanka. The green parts of the plant are used as a vegetable or as fodder for cattle. The seeds contain a high amount of protein and B-vitamins (Phillips R.D et al. 1991) and help to prevent starvation among low resource farmers and the poor urban population (Duke, 1983).

Many diseases, viruses and insect pests (Bottenberg, 1995; Jackai, et al., 1986) attack the legumes in the field, but once the crop is harvested the problems are not over. In the field, several beetle species lay their eggs on the surface of the maturing pod or directly on the testa of the ripening seed and can thus be brought to the storage room with the harvested beans (Lale et al., 1999; Warui, 1984). The larvae of these beetles develop inside the bean, destroying its contents. After a few weeks, new adults emerge, leaving the bean a perforated seed with a low probability of germination (Singh et al., 1994).

\section{DISCUSSION}

\section{Control measures against storage beetles}

There are many methods known to prevent or reduce damage done by the cowpea weevil. The most common control measures taken against storage beetles are:

\section{Synthetic pesticides}

Some chemicals have proven to be very effective against bruchid damage if they are used at the right time, in the right quantities, with the right application method, etc.

\section{Hermetic storage}

Storage beetles can penetrate plastics up to $0.818 \mathrm{~mm}$ thick (Shukla et al., 
1993) but thick plastic bags can be used to store beans (Singh, 1995) especially if they are used with a cotton inner lining (Caswell, 1973).

\section{Natural enemies}

Developing bruchid beetles can be parasitized by egg parasites such as Uscana lariophaga or by the larval or pupal parasites such as Dinarmus basalis and Eupelmus vuilleti.

\section{Inert materials}

Sand or ash can be mixed with stored beans to make an effective barrier against the beetles which prevents the emerged adults from finding each other for mating or from reaching a next bean to oviposition.

\section{Physical methods}

In a (solar) heater, or in plastic bags exposed to the sun (Ahmed et al., 1992),more than one hour, all stages of the bruchid are killed whereas the cooking properties and germination of the beans are not negatively influenced (Cockfield, 1992).

\section{The use of plant products as protectants}

Plant products could offer a solution for the problems of availability, health risks, costs and resistance in the case of synthetic pesticides, and for the lack of equipment for hermetic storage, gamma irradiation and controlled atmospheres

The mixing with plant oils is an ancient Indian and African method of protecting grains against insect attack (Pereira, 1983) and most of the reported studies with plant oils have involved use against stored grain insect pests. An increasing number of plant oils have been screened for preventing post-harvest losses due to insects (Golob and Webley, 1980). Several authors have reported the use of plant oils against Callosobruchus adults and oviposition by females. Varma and Pandey (1978) showed that groundnut and other oils applied at $0.3 \% \mathrm{w} / \mathrm{w}$ gave complete protection of green gram Vigna aureus (Roxb.) against $C$. maculatus $(\mathrm{Cm})$ in laboratory bioassays. However, Singh et al. (1978) reported that groundnut oil applied to cowpeas has no effect on mortality or longevity of adult $C$. maculates. Tikku et al. (1981) similarly showed that topical application of several vegetable oils, including groundnut and coconut oils, had no effect on mortality of adult $C$. chinensis $(\mathrm{Cc})$. In contrast, Hill and van Schoonhoven (1981) found that palm oil killed adult $C$. maculates. Single et al. (1978) proposed that the toxicity of vegetable oil was primarily to the eggs of $C$. maculates, and that the effect was both physical and chemical. This view was supported by van Schoonhoven (1978) who showed that vegetable oils of different purity varied in toxicity to eggs. Gunther and Jeppson (1960) stated that the action of oils was probably more complex than simple physical interference with egg or adult respiration, as adult insects deprived of oxygen survived longer than those treated with oils. In summary, there have been various reports of oils survived longer than those treated with oils. In summary, there have been various reports of oils causing reduced oviposition and higher egg and adult mortality, but all do not agree (van Huis, 1991), and there have generally been great discrepancies about the extent of protection offered by these oils against stored products insects (van Schoonhoven, 1978; Pereira, 1983; Doharey et al., 1988). 
The use of plant products as insecticides could be broadly classified under (a) Powders or fresh application,

(b) Volatile oils (c) Non volatile oils

(d) Extracts in application technology

\section{Powders or fresh application}

The simplest way to apply plants to a stock of seeds is harvesting the plant and adding it to the seeds.
Many plants have been tested in the laboratory as powders to estimate their possible effects. The Modes of action of these powders vary, but with low to moderate dosages, the effect is always repellent or toxic, never mechanical.

Table 01: Plants used against storage insects, the quantity and the used plant part.

\begin{tabular}{|c|c|c|c|c|c|c|c|c|c|c|c|}
\hline \multirow{2}{*}{$\begin{array}{l}\text { Plant (sub-) } \\
\text { family }\end{array}$} & \multirow{2}{*}{$\begin{array}{l}\text { Plant } \\
\text { species }\end{array}$} & \multirow{2}{*}{$\begin{array}{l}\text { Plant } \\
\text { part \$ }\end{array}$} & \multirow[t]{2}{*}{ Quantity } & \multirow{2}{*}{$\begin{array}{c}\text { Beetle } \\
\text { species } \\
\wedge\end{array}$} & \multicolumn{7}{|c|}{ Affected stage \# } \\
\hline & & & & & A & $\mathrm{O}$ & $\mathrm{E}$ & $\mathrm{H}$ & $\mathrm{L}$ & $\mathrm{M}$ & $\mathrm{P}$ \\
\hline \multirow[t]{3}{*}{ Annonaceae } & Annona & $\mathrm{S}$ & 50 & $\mathrm{Ca}$ & !! & !! & & & & & !! \\
\hline & squamosa & $\mathrm{S}$ & $5-100$ & $\mathrm{Ca}$ & $* !$ & $* !$ & & & & & \\
\hline & & $\mathrm{S}$ & $10-50$ & $C c$ & & $* !$ & & & & $* !$ & $* !$ \\
\hline \multirow[t]{5}{*}{ Araceae } & Acorus & -- & $5-20$ & $C c$ & & !! & & & & $* !$ & \\
\hline & calamus & $\mathrm{R}$ & $5-20$ & $C c$ & & & & & & & $* !$ \\
\hline & & $\mathrm{R}$ & $10-50$ & $C c$ & & $* !$ & & & & $* !$ & $* !$ \\
\hline & & $\mathrm{T}$ & $0.5-5 \%$ & Cc, So & $* !$ & & & & & & \\
\hline & & $\mathrm{R}$ & $1-2 \%$ & $\mathrm{Cm}$ & & & & & & & $* !$ \\
\hline Lamiaceae & $\begin{array}{l}\text { Ocimum } \\
\text { sanctum }\end{array}$ & $\mathrm{L}$ & $\begin{array}{l}0.1-0.4 \mathrm{~g} / \\
50 \text { seeds }\end{array}$ & $\mathrm{Cm}$ & $* !$ & & & $* !$ & & $* !$ & \\
\hline
\end{tabular}

( $\mathrm{S}=$ seeds, $\mathrm{R}=$ rhizomes, roots $\mathrm{T}=$ twigs, $\mathrm{L}=$ leaves, $\mathrm{P}=$ peels, $\mathrm{B}=$ bark, $\mathrm{BR}=$ root bark, $\mathrm{Bu}=$ bulb, $\mathrm{F}=$ fruits, $\mathrm{FI}=$ flowers, $\mathrm{G}=$ green parts, $\mathrm{K}=$ kernels, $\mathrm{Tu}=$ tuber, $\mathrm{W}=$ wood, !!=total inhibition, $* !=$ Significant decrease, $* *=$ Measured, but statistically not significant

$\mathrm{A}=$ adult longevity and fecundity, $\mathrm{O}=$ oviposition, $\mathrm{H}=$ hatching, $\mathrm{M}=$ emergence, $\mathrm{L}=$ survival of larvae, $\mathrm{P}=$ population numbers and effect on stored product,

$\mathrm{Ca}=$ Callosobruchus analis, $\mathrm{Cm}=$ Callosobruchus maculates, $\mathrm{So}=$ Sitophilus oryzae, $\mathrm{Cc}=$ Callosobruchus chinensis, $\mathrm{Rd}=$ Rhixopertha dominica, $\mathrm{Sz}=$ Sitophilus zeamays)

\section{Effects on Adults}

Toxicity, either through fumigation or through direct contact, is usually the major action of plant powders against adult insects in laboratory tests. In the literature, toxicity levels vary widely, from slight toxicity to induction of complete mortality of all adult insects. Leaves and kernels of Azadirachta indica slightly increased adult mortality of Cm (Seck et al., 1991). Leaves of Piper nigrum caused adult mortality for Cm (Rajapakse, 1989) at the doses of 0.20 grams $/ 50$ seeds. The toxicity was attributable to the presence of piperine ( $\mathrm{Su}, 1977)$.

\section{Effects of Oviposition}

If plant powders reduce adult longevity and fitness, the numbers of eggs laid will often be lower as well. Moreover, the mechanical effect of large quantities of powders themselves could have an effect on oviposition. Rajapakse and Van Emden (1997) reported that the number of eggs laid by 3 bruchid spps was significantly reduced in treatments to which powders of Cymbopogan citratus, Cinnamomum camphora, Derris inudata, Monodora myristica Zingiber spectabile is added. 
Citrus peels Citrus paradise, Citrus aurantifolia (Onu e al., 1997) and Citrus crematifolia (Rajapakse, 1990), root bark of Zanthoxylum zanthoxyloides (Ogunwolu et al. 1996), fruits of Curcuma longa and Eugenia aromatica (Javaid et al. 1995), Azadirachta indica, Anacardium occidentale and Zingiber officinale all decreased the number of eggs laid by C. maculatus (Echendu, 1991).

Plant powders often prevent or reduce the mergence of adult beetles from the seed. However, it is not clear if this effect is caused by larval mortality, or by the fact that the merging adults contact the plant powder while gnawing their way out of the seed.

Anacadium occidentale, Zingiber officinale and Azadirachta indica (Echendu, 1991) and peels of Citrus paradisi and Citrus aurantifolia significantly decreased infestation and emergence of C. maculatus (Onu et al., 1997). Seeds of Azadirachta indica had the same effects and they prolonged the developmental period of the beetle as well (Ivbijaro, 1983). Rajapakse et al (1998) reported that Azadirachta indica gave highest reduction in oviposition and adult emergence of C. maculatus and Citrus limon powder gave highest adult mortality 6 days after treatment.

Sometimes plant powders are found to have an effect opposite of what was aimed for. High concentrations of intact leaves of Ocimum basilicum increased hatching and progeny emergence (Weaver et al., 1994)

\section{Volatile Oils}

From some aromatic plants volatile oils can be extracted. These oils can be applied to stored seeds as protectants against storage insect' pests. The yield of oil is usually low, but due to repellence or toxicity, even small amounts of the concentrated essential extract can be very effective in airtight or hermetic storage structures. A major advantage of volatile insecticides is that they do not need to be mixed with the seeds. No physical contact is needed between seeds and protectant. The effect or these volatile oils is usually reached through fumigation.

\section{Effects on Adults}

Volatile oils mostly affect adult beetles. The vapours usually have a repellent effect, causing the beetles to flee from the store, or not to invade it at all.

Formulations of Acorus calamus all showed an excellent knockdown effect on $C$. chinensis and a long lasting residual effect (Su, 1977).

However, contact toxicity has been found to also play an important role against beetles. Topical application of eight lyophilized citrus peel oils showed high toxicity to C.maculatus adults (Su et al., 1972).

\section{Effects on Oviposition}

The number of eggs laid is often reduced after treatment with volatile oils. This effect on oviposition can be caused, among others, the reduced longevity of the adult insects.

In most cases, a reduction of oviposition is mentioned, without the possible cause Cymbopogon citrates, Eugenia uniflora, Lantana camara and Lippia adoensis completely inhibited oviposition and adult emergence of $C$. maculatus. 
Table 02: Plants of which the volatile oil is used against storage insects, the quantity of oil used and its effect

\begin{tabular}{|c|c|c|c|c|c|c|c|c|c|c|}
\hline \multirow{2}{*}{$\begin{array}{l}\text { Plant } \\
\text { (sub-) } \\
\text { family }\end{array}$} & \multirow[t]{2}{*}{ Plant species } & \multirow[t]{2}{*}{ Quantity- } & \multirow{2}{*}{$\begin{array}{l}\text { Beetle } \\
\text { species } \\
\wedge\end{array}$} & \multicolumn{7}{|c|}{ Affected stage \# } \\
\hline & & & & A & $\mathrm{O}$ & $\mathrm{E}$ & $\mathrm{H}$ & $\mathrm{L}$ & M & $P$ \\
\hline \multirow[t]{8}{*}{ Araceae } & Acorus & $2-4 \%$ & $C c$ & $* !$ & & & & & & \\
\hline & calamus & $1-7$ & $C c$ & $* !$ & & & & & & \\
\hline & & $\mu 1 /$ insect & C. So & $* 1$ & & & & & & \\
\hline & & $\begin{array}{l}2.5-125 \\
2-51\end{array}$ & $\begin{array}{l}C c, R d, \\
\text { So }\end{array}$ & *! & & $* !$ & & & & \\
\hline & & $10 \mu 1$ & $\begin{array}{l}\text { Cc, Sg, } \\
\text { So }\end{array}$ & $* !$ & & $* !$ & & & & \\
\hline & & $10-50 \mu 1$ & $C c, S o$ & & & $* !$ & & ** & ** & \\
\hline & & $25-125$ & $C c, S o$ & $* !$ & & & & & $* !$ & \\
\hline & & $12.5-25$ & $\mathrm{Cm}$ & $! !$ & $* !$ & $* !$ & & & $* !$ & \\
\hline \multirow[t]{5}{*}{ Lamiaceae } & Осітит & $5-10 \mathrm{~g} / \mathrm{kg}$ & Ao & & & & & ** & !! & \\
\hline & basilicum & $1-10 \%$ dip & $C c$ & $* !$ & $* !$ & & !! & & $! !$ & \\
\hline & & $\begin{array}{l}0.05-0.17 \\
\mu 1 / \text { insect }\end{array}$ & $\mathrm{Cm}$ & $* !$ & & & & & & \\
\hline & & $\begin{array}{l}1-37.5 \\
\mu 1 / \text { insect }\end{array}$ & $\mathrm{Cm}$ & $* !$ & $* !$ & & ** & & $* !$ & \\
\hline & & $0.2-\mathrm{ml} / \mathrm{kg}$ & $\mathrm{Cm}, \mathrm{So}$ & $* !$ & & & & & & \\
\hline \multirow[t]{9}{*}{ Poaceae } & Cymbopogon & $1-10 \% \operatorname{dip}$ & $C c$ & $* !$ & $* !$ & & $* !$ & & $* !$ & \\
\hline & citrates & $\begin{array}{l}0.5-30 \\
\mu 1 / 50\end{array}$ & $\mathrm{Cm}$ & & $! !$ & & & & $! !$ & \\
\hline & & seeds & & & & & & & & \\
\hline & & $2-8 \mathrm{~g} / \mathrm{kg}$ & $\mathrm{Cm}$ & & $* !$ & & & & & \\
\hline & & $\begin{array}{l}5-40 \mu 1 / 50 \\
\text { seeds }\end{array}$ & $\mathrm{Cm}$ & & $! !$ & & & & $* !$ & \\
\hline & & $6.7-33.3$ & $\mathrm{Cm}$ & $* !$ & $* !$ & & & & $! !$ & \\
\hline & & $6.6-33.3$ & $\mathrm{Cm}$ & & & & !! & $! !$ & & \\
\hline & & $6.7-33.3$ & $\mathrm{Cm}$ & $* *$ & $* !$ & & & & & \\
\hline & & $4-8 \mathrm{~g} / \mathrm{kg}$ & $\mathrm{Cm}$ & & $* !$ & & & & & \\
\hline
\end{tabular}

\section{Effects on eggs and Larvae}

The juvenile stages of the storage insects are generally less affected by volatile oils than the adult beetles, but they are usually not completely tolerant to the treatments. Eggs of $C$. chinensis were susceptible to vapours of Acorus calamus.

Application is easy, but should be repeated for-long term protection. The insecticide does not usually need to touch the stored product, so the product is mostly unaffected by the treatment.

\section{Non-volatile oil}

Non-volatile oil, used as a coating for seeds, can effectively protect these seeds against insect pests during storage. The film of oil prevents the attachment of the egg to the seed coast and plugs the respiratory systems of eggs and adults beetles.

However, most of the oils are very effective and retain their effectiveness over a long period. 
Table 03: Plants of which the no-volatile oil is used against storage insects, the quantity of oil used and its effect.

\begin{tabular}{|c|c|c|c|c|c|c|c|c|c|c|}
\hline \multirow{2}{*}{$\begin{array}{l}\text { Plant (sub-) } \\
\text { family }\end{array}$} & \multirow[t]{2}{*}{ Plant species } & \multirow[t]{2}{*}{ Quantity } & \multirow{2}{*}{$\begin{array}{c}\text { Beetle } \\
\text { species }^{\wedge}\end{array}$} & \multicolumn{7}{|c|}{ Affected stage \# } \\
\hline & & & & A & $\mathrm{O}$ & $\mathrm{E}$ & $\mathrm{H}$ & $\mathrm{L}$ & M & $\mathrm{P}$ \\
\hline \multirow[t]{27}{*}{ Aracaceae } & Cocos & $1-20$ & $C c$ & $* !$ & $* !$ & & & & & \\
\hline & nucifera & 10 & $\mathrm{Cm}$ & !! & !! & & & & & ** \\
\hline & & $1-4$ & $\mathrm{Ca}$ & & $* !$ & & & & $* !$ & $* !$ \\
\hline & & $5-10$ & $C c$ & !! & !! & !! & & !! & !! & \\
\hline & & 3 & $C c$ & $* *$ & $* ! * !$ & & & & & \\
\hline & & $0.5-3$ & $C c$ & & & & & & & $* !$ \\
\hline & & 10 & $C c$ & !! & & & & & & \\
\hline & & 10 & $C c$ & $* !$ & & & & & & \\
\hline & & $0.5 \%$ & $C c$ & & & & & & & $* !$ \\
\hline & & $50 \mathrm{~g} / \mathrm{kg}$ & $C c$ & & & & & & & $* !$ \\
\hline & & $0.5-5$ & $C c$ & & & & & & $* !$ & \\
\hline & & $1-4$ & $C c$ & & & & & & & $* !$ \\
\hline & & $2-4$ & $C c$ & & $* !$ & & & & & $* !$ \\
\hline & & $5-75$ & $C c$ & & & & & & & $* !$ \\
\hline & & $1-5$ & $C c$ & & $* !$ & & & & $* !$ & $* !$ \\
\hline & & $1-3$ & $C c$ & & $* !$ & & & & $* !$ & \\
\hline & & $1-8,3 \mathrm{~g} / \mathrm{kg}$ & $\mathrm{Cc}, \mathrm{Cm}$ & & & & & & & $* !$ \\
\hline & & $150 \mu /$ bean & $\mathrm{Cc}, \mathrm{Cm}$ & & & & $* !$ & & & \\
\hline & & $1-10 \mathrm{~g} / \mathrm{ka}$ & Cc, So & $* !$ & $* !$ & $* !$ & & & $* !$ & \\
\hline & & $3 \%$ & $C c, S z$ & $* !$ & & & & & & \\
\hline & & $2-8 \mathrm{~g} / \mathrm{kg}$ & $\mathrm{Cm}$ & & $* !$ & & & & & \\
\hline & & $3.5-14$ & $\mathrm{Cm}$ & $* *$ & $* !$ & $* !$ & & & & \\
\hline & & $1.75-14$ & $\mathrm{Cm}$ & & & $* !$ & $* !$ & & & \\
\hline & & Dipped & $\mathrm{Cm}$ & $* *$ & ** & $* !$ & & & & \\
\hline & & 5 & $\mathrm{Cm}$ & & $* !$ & $* !$ & & $* !$ & $* !$ & \\
\hline & & $2.5-10$ & $\mathrm{Cm}$ & & $* *$ & & ** & & $* !$ & \\
\hline & & $2.5-10$ & $\mathrm{Cm}$ & & & & & & $* *$ & ** \\
\hline Leguminosae- & Arachis & 10 & $\mathrm{Cm}$ & !! & !! & & & & & ** \\
\hline \multirow[t]{26}{*}{ Papilionoideae } & hypogaea & $5-10$ & $\mathrm{Cm}$ & $* !$ & & $* !$ & & & & \\
\hline & & $1-4$ & $\mathrm{Ca}$ & & $* !$ & & & & $* !$ & $* !$ \\
\hline & & 3 & $C c$ & ** & *! & $* !$ & & & & \\
\hline & & $0.5-3$ & $C c$ & & & & & & & $* !$ \\
\hline & & $5-10$ & $C c$ & & $* !$ & & $! !$ & & & \\
\hline & & $5-10$ & $C c$ & & & & & & $* !$ & $* !$ \\
\hline & & $5-10$ & $C c$ & ** & ** & & & & & \\
\hline & & 10 & $C c$ & & $* !$ & & & & & \\
\hline & & $0.5 \%$ & $C c$ & & & & & & & $* !$ \\
\hline & & $50 \mathrm{~g} / \mathrm{kg}$ & $C c$ & & & & & & & !! \\
\hline & & $0.5-5$ & $C c$ & & & & & & $* !$ & \\
\hline & & $2.5-10$ & $C c$ & & & ** & & & & \\
\hline & & $1-4$ & $C c$ & & & & & & & $* !$ \\
\hline & & 2.4 & $C c$ & & $* *$ & & & & & $* !$ \\
\hline & & $5-75$ & $C c$ & & & & & & & $* !$ \\
\hline & & $1-5$ & $C c$ & & $* !$ & & & & $* !$ & $* !$ \\
\hline & & $1-3$ & $C c$ & & $* !$ & & & & $* !$ & \\
\hline & & 2.8 & $C c$ & & ** & & !! & & !! & \\
\hline & & $1-10,3 \mathrm{~g} / \mathrm{kg}$ & $\mathrm{Cc}, \mathrm{Cm}$ & & $* !$ & & & & & !! \\
\hline & & $150 \mu \mathrm{g} /$ been & $\mathrm{Cc}, \mathrm{Cm}$ & & & & $* !$ & & & \\
\hline & & $5-10$ & $\mathrm{Cc}, \mathrm{Cm}$ & $* *$ & $* !$ & & & & & \\
\hline & & $1-10 \mathrm{~g} / \mathrm{kg}$ & Cc, So & $* *$ & $* !$ & $* !$ & & & $* !$ & \\
\hline & & $5-10$ & $\mathrm{Cm}$ & & & !! & & & & \\
\hline & & 5 & $\mathrm{Cm}$ & & & & & & & $* !$ \\
\hline & & $2-8 \mathrm{~g} / \mathrm{kg}$ & $\mathrm{Cm}$ & & $* !$ & & & & & \\
\hline & & Flour pellets & $\mathrm{Cm}$ & $* !$ & $* !$ & & & $! !$ & *! & \\
\hline
\end{tabular}




\section{Developmental stage affected}

\section{Effects on adults}

Non-volatile oils can have negative effects on adult beetles, either through contact toxicity or through deterrence. Cocos nucifera (Jacob, 1994), Madhuca longifolia, Sesamum indicum, Azadirachta indica, and Elaeis guineensis inflicted complete adult mortally for $C c$ (Ali et al., 1983). Rajapakse and Van Emden (1997) reported that the longevity of Adults of C.maculatus amd C.chinensis were significantly reduced

\section{Effects on oviposition}

Oviposition can be influenced by treatment of the stored product with non-volatile oil. Rajapakse and VanEmden ( 1997) reported that the four oils tested corn groundnut, sunflower and sesame reduced oviposition of all three bruchid species tested.The decrease in the number of eggs could be due to other causes than just the effect on the longevity of the adult beetle. Oviposition of $C$. maculates was completely inhibited after seed treatment with Pongamia pinnata (Bhaduri et al., 1990).

\section{Effects on eggs and larvae}

Most of the efficacy on non-volatile oils can be attributed to the effect on eggs and their attachment to the seed coat. The effect of the oils is at least partly based on mechanical action. Due to the oil layer around treated seeds, eggs cannot be attached effectively to the seed surface. Hatching of first instar larvae is prevented because penetration is more difficult if egg attachment is less secure (Don-Pedro, 1989).

In addition to the mechanical effects, a combination of mechanical and toxic effects could occur.

\section{Extracts}

Extracting plant material with an appropriate solvent generally results in concentration of active ingredients. Such extracts are therefore often more effective against storage beetle than powders or fresh plants. Usually, the extract is mixed with the beans as a liquid, and the solvent evaporates before the beans are stored. Disadvantages that have been mentioned are that extracts are mostly difficult or laborious to make and yields are usually low. The solvents are mostly not available for low resource farmers and large quantities of plant materials are needed.

\section{Effects on adults}

Extracts often have an effect on adults, either acting as repellent, a toxicant, or a combination of these two actions. Rajapakse ( 2000) reported that out of 20 plat oil extracts tested 3 oil extracts showed some bioactivity, 9 extracts caused significant adult mortality and 6 extracts inflicted $41-100 \%$ egg mortality in both spp of C.maculatus and C.chinensis

\section{Effects on oviposition}

The effects on adults cause effects on oviposition, numbers of offspring etc. In some cases, the eggs that have been laid are affected as well. 
Table 04: Plants of which extracts are used as protective agents against storage beetles, the solvent, the extracted plant part, the quantity and the effect

\begin{tabular}{|c|c|c|c|c|c|c|c|c|c|c|c|}
\hline \multirow{2}{*}{$\begin{array}{l}\text { Plant (sub-) } \\
\text { family }\end{array}$} & \multirow{2}{*}{$\begin{array}{l}\text { Plant } \\
\text { species }\end{array}$} & \multirow{2}{*}{$\begin{array}{l}\text { Solvent } \\
*\end{array}$} & \multirow{2}{*}{$\begin{array}{l}\text { Plant } \\
\text { part } \\
\$\end{array}$} & \multirow{2}{*}{$\begin{array}{l}\text { Quantity } \\
-\end{array}$} & \multirow{2}{*}{$\begin{array}{l}\text { Beetle } \\
\text { species } \\
\wedge\end{array}$} & \multicolumn{3}{|c|}{ Affected stage \# } & \multirow[b]{2}{*}{$\mathrm{L}$} & \multirow[b]{2}{*}{$\mathrm{M}$} & \multirow[b]{2}{*}{$\mathrm{P}$} \\
\hline & & & & & & A & $\mathrm{O}$ & E H & & & \\
\hline \multirow[t]{2}{*}{ Liliaceae } & \multirow[t]{2}{*}{$\begin{array}{l}\text { Allium } \\
\text { sativum }\end{array}$} & $\mathrm{PE}$ & $\mathrm{B}$ & $\begin{array}{l}10-50 \\
\mathrm{~g} / \mathrm{kg}\end{array}$ & $C c$ & & & & & & $* !$ \\
\hline & & PE & -- & $1.3 \%$ & $\mathrm{Cm}$ & & & & & & $* !$ \\
\hline \multirow[t]{4}{*}{ Piperaceae } & \multirow[t]{4}{*}{$\begin{array}{l}\text { Piper } \\
\text { guineense }\end{array}$} & Et & $\mathrm{S}$ & $\begin{array}{l}12.5- \\
37.5 \mathrm{~g} / \mathrm{kg}\end{array}$ & $\mathrm{Cm}$ & $* !$ & $! !$ & & & $! !$ & \\
\hline & & PE-Me & $\mathrm{Fr}$ & $5 \mathrm{~g} / \mathrm{kg}$ & $\mathrm{Cm}, \mathrm{Sz}$ & $* !$ & $* !$ & & & $* !$ & \\
\hline & & $\mathrm{He}$ & $\mathrm{Fr}$ & $\begin{array}{l}5-40 \mathrm{~g} / 1, \\
0.5 \mu \mathrm{l}\end{array}$ & $\mathrm{Cm}, \mathrm{So}$ & $* !$ & & & & *! & \\
\hline & & Es & $\mathrm{Fr}$ & $\begin{array}{l}2-10 \\
\mathrm{~g} / \mathrm{kg}\end{array}$ & $\mathrm{Cm}$, So & $* *$ & & & & & \\
\hline Solanaceae & $\begin{array}{l}\text { Capsicum } \\
\text { аппиит }\end{array}$ & Ac & $\mathrm{Fr}$ & $\begin{array}{l}1.25- \\
10 \% \\
200\end{array}$ & $\mathrm{Cm}$ & & $* !$ & & & ** & \\
\hline
\end{tabular}

\section{Effects on eggs and larvae}

Eggs and young larvae can be affected by extracts whereas older larvae are usually less susceptible. Piper guineense caused egg mortality of $C$ maculatus, (Mbata et al., 1992).

Extracts are usually more effective than powders. They are mostly effective against adult beetles, either as repellents or as toxicants. Other developmental stages of the beetle can be susceptible as well. The effect of extracts on the stored product is usually negligible. Large quantities of plants are often needed to obtain sufficient amounts of extracts. Solvent availability can impose a limitation on the use of extracts.

\section{References}

Ahmed S.M. \& A. Ahamad., (19920). Efficacy of some indigenous plants as pulse protectants against Callosoburuchus chinensis (L.) infestation. International Pest Control, 34: 54-56.

Ali S.I., O.P. Singh \& U.S.Misra., (1983). Effectiveness of plant oils against pulse beetle Callosobruchus chinensis Linn. Indian Journal of Entomology, 45: 6-9.

Bhaduri N., D.P. Gupta, \& S.Ram, (1990). Effect of vegetable oils on the ovipositional behaviour of Callosobruchus maculates (Fabricius). In: Fujii K., Gatehous A.M.R., Johnson C.D., Mitchel R. \& Yoshida T. (Eds.). Bruchids and Legumes: Economics, Ecology and Coevolution. Proceedings of the Second International Symposium on Bruchids and Legumes, Okayama, Japan, pp 81-84.

Biradarpatil N.K., M.Shekhargound \& R.S.Giraddi, (1995). Viability of Bengal gram seeds infested with bruchids. Seed-Research, 23: 58-59.

Bottenberg H., (1995). Farmers' perceptions of crop pests and pest control practices in rainfed cowpea cropping systems in Kano, Nigeria. International Journal of Pest Management, 41: 195-200.

Caswell G.H., (1973). The storage of cowpea. Samaru Agriculture Newsletter, 15: 73-75. 
Cockfield S.D., (1992). Groundnut oil application and varietal resistance for control Callosobruchus maculates (F.) in cowpea grain in The Gambia. Tropical Pest Management, 38: 268-270.

Doharey R.B., R.N. Katiyar and K.M. Singh. (1988). Effect of edible oils in protection of greengram Vigna radiate seed from pulse beetles Callosobruchus chinensis and Callosobruchus maculates. Journal of Agricultural Sciences 58, 151-154.

Don-Pedro K.N., (1989). Mode of action of fixed oils against eggs of Callosobruchus manulatus (F.). Pesticide Science, 26: 107-115.

Duke J.A., (1983). Handbook of Energy Crops. Unpublished.

Echendu T.N.C., (1991). Ginger, cashew and neem as surface eprotectants of cowpeas against infestation and damage by Callosobruchus maculates (Fab.). Tropical Science, 31: 209-211.

Golob P. and O.J. Webley. (1980). The use of plants and minerals as traditional protectants of stored products. Bulletin of the Tropical Products Institute of $O D A, U K 12-13$.

Gunther F.A. and L.R. Jeppson. (1960). Modern Insecticides and World Food Production. 284 pp. Wiley, New York.

Hill J. and A.Van Schoonhoven, (1981). Effectiveness of vegetable oil fractions in controlling the Mexican bean weevil of stored beans. Journal of Economic Entomology 74, 478-479.

Van Huis A., (1991). Biological methods of bruchid control in the tropics: A review. Insect Science and its Application 12, 110-113.

Ivbijaro M.F., (1983). Preservation of cowpea, Vigna unguiculata (L.) Walp, with the neem seed, Azadirachta indica A. Juss. Protection Ecology, 5: 177-182.

Jackai L.E.N., and R.A.Daoust, (1986). Insect pests of cowpea. Annual Review of Entomology, 31: 95-119.

Jacob S., (1994). Efficacy of coconut oil in protecting different pulse grains from the pulse beetle, Callosobruchus chinensis Linn. Indian Coconut Journal 25: 14, 19.

Javaid I. \& M.A.T. Poswal., (1995). Evaluation of certain speces for the control of Callosobruchus maculates (Fabricius) (Coleoptera: Bruchidae) in cowpea seeds. African Entomology, 3: 87-89.

Labeyrie V., (1981). Vaincre la carence proteiquie par le development des Legumineuses alimentaires et la protection de leurs recoltes contre les bruches. Food and Nutrition Bulleting, 3: 24-38.

Lal N.E.S. \& H.T. Abdulrahman, (1999). Evaluation of neem (Azadirachta indica A. Juss) seed oil obtained by different methods and neem powder for the management of Callosobruchus maculates (F.) (Coleoptera: Bruchidae in stored cowpea. Journal of Stored Products Research, 35: 135-143.

Mbata G.N. \& O.T. Ekpendu, (1992). The insecticidal action of four botanicals against three storage beetles. International Symposium on Crop Protection. Mededelingen van de Faculteit Landbouwwetenschappen, Rijksuniversiteit Gent, 57: 723-733.

Ogunwolu E.O. \& A.T. Odunlami, (1996). Suppression of seed bruchid (Callosobruchus maculates F.) development and damage on cowpea (Vigna unguiculata (L.) Walp.) with Zanthoxylum zanthoxyloides (Lam.) Waterm. (Rutaceae) root bark powder when compared to neem seed powder and pirimiphos-methyl. Crop Protection, 15: 603-607. 
Onu I. \& A. Sulyman, (1997). Effect of powdered peels of citrus fruits on damage by Callosobruchus maculates (F.) to cowpea seeds. Journal of Sustainable Agriculture, 9: 85-92.

Pereira J., (1983). The effectiveness of six vegetable oils as protectants of cowpeas and banbara groundnuts against infestation by Callosobruchus maculaturs (F.). Indian Journal of Agricultural Sciences 51, 910-912.

Phillips R.D. \& K.H. McWatters, (1991). Contribution of cowpeas to nutrition and health. Food Technology, 45: 127-130.

Quin F.M., (1997). Introduction. In:Singh B.B., Mohan Raj D.R., Dashiell K.E. \&Jackai L.E.N. (Eds.. Advances in Cowpea Research. IITA and JIRCAS, pp ix-Xv.

Rajapakse R.H.S., (1989). Status of Bruchid research in Sri Lanka: Country report: In: Yoshida T. (Ed.) Proceedings of the Second International Symposium of Bruchids and Legumes, Okayama, Japan, pp 38-43.

Rajapakse R.H.S., (1990). Effect of five botanicals as protectants of greegram against the pulse beetle Callosobruchus maculates. In: Fujii K., Gatehouse A.M.R., Johnson C.D., Mitchel R. \& Yoshida T. (Dds.). Bruchides and Legumes: Economics, Ecology and Coevolution. Proceedings of the Second International Symposium on Bruchids and Legumes, Okayama, Japan, pp 8590.

Rajapakse R.H.S., (2000). Pesticidal potential of tropical plants-insecticidal activity of some selected natural products against Callosobruchus maculates and $C$. chinensis. Proc. Entomo. Congress Trivandrum, India.

Rajapakse R. \& H.F., Van Emden (1997). Potential of four vegetable oils and ten botanical powders for reducing infestation of cowpeas by Callosobruchus maculates, C. Chinensis and C. rhodesianus. Journal of Stored Products Research, 33: 59-68.

Van Schoonhoven A., (1978). Use of vegetable oils to protect stored beans from bruchid attac,. Journal of Economic Entomology 71, 254-256.

Seck D., B.Sidibe, E. Haubruge \& C.Gaspar, (1991). La protection des stocks de niebe (Vigna unguiculata (L). Walp.)en milieu rural: utilization de differentes formulations a base de neem (Azadirachta indica A. Juss.) provenant du Senegal. Mededelingen van de Faculteit Landbouwwetenschappen, Jijksuniversiteit Gent, 56: 1217-1224.

Shukla R.M., G. Chand, M. Chandra \& M.L. Saini, (1993). Comparative resistance of different packing materials to stored grain insects. Plant Protection Bulletin Faridabad, 45: 21-23.

Singh G., (1995). Use of polythene bags to check infestation by pulse beetle, Callosobruchus maculates Fab. In stored moong. Journal of Insect Science, 8: 212-214.

Singh O.P., J.P. Gujrati \& N. Khandwe, (1994). Effect of pulse beetle, Callosobruchus chinensis Linn. Infestation on storage and germination losses to soybean in Madhya Pradesh, India. Annals of Entomology, 12: 37-38.

Singh S.R., R.A. Luse, K. Leuschner and D. Nangju (1978). Groundnut oil treatment for the control of Callosobruchus maculates (F.). Journal of Stored Products Research 14, 77-80.

Su H.C.F., (1977). Insecticidal properties of black pepper to rice weevils and cowpea weevils. Journal of Economic Entomology, 70: 18-21. 
Su H.C.F., R.D Speirs. \& P.G.Mahany, (1972). Toxicity of citrus oils to several stored-product insects: laboratory evaluation. Journal of Economic Entomology, 65: 1438-1441.

Tikku K., O.Koul and B.P.Saxena (1981). Possible mode of action of vegetable oils in protection of Phaseolus aureus Roxb. From bruchid attack. Science and Culture 41, 103-105.

Varma B.K. and G.P. Pandey (1978). Treatment of stored greengram with edible oils for protection from Callosobruchus maculates (F.). Indian Journal of Agricultural Sciences 48, 72-75.

Warui C.M., (1984). Bruchid infestation of cowpea varieties in the field. Insect Science and its Application, 5: 283-286.

Weaver D.K., F.V.Dunkel, R.C.Potter \& L.Ntezurubanza, (1994). Contact and fumigant efficacy of powdered and intact Ocimum canum Sims (Lamiales: Lamiaceae) against Zabrotes subfasciatus (Boheman) adults (Coleoptera: Bruchidae). Journal of Stored Products Research, 30: 243-252. 